\title{
ArcheoSciences
}

Revue d'archéométrie

\section{Bronze Age gold in Southern Georgia}

L'or en Géorgie du sud à l'Âge du Bronze

\section{Andreas Hauptmann and Sabine Klein}

\section{OpenEdition}

\section{Journals}

Electronic version

URL: https://journals.openedition.org/archeosciences/2037

DOI: 10.4000/archeosciences.2037

ISBN: 978-2-7535-1598-7

ISSN: 2104-3728

Publisher

Presses universitaires de Rennes

Printed version

Date of publication: 31 December 2009

Number of pages: $75-82$

ISBN: 978-2-7535-1181-1

ISSN: $1960-1360$

\section{Electronic reference}

Andreas Hauptmann and Sabine Klein, "Bronze Age gold in Southern Georgia", ArcheoSciences [Online], 33 | 2009, Online since 09 December 2011, connection on 01 February 2022. URL: http://

journals.openedition.org/archeosciences/2037 ; DOI: https://doi.org/10.4000/archeosciences.2037

Article L.111-1 du Code de la propriété intellectuelle. 


\title{
Bronze Age gold in Southern Georgia L'or en Géorgie du sud à l'Âge du Bronze
}

\author{
Andreas HauptmanN* and Sabine KLein**
}

\begin{abstract}
This study represents a joint pilot project between archaeological and natural sciences, aimed at exploring the technology and provenance of gold artefacts, exemplified for the case of Georgia. It is focussed on the prehistoric gold mine of Sakdrisi. The study included the investigation of both Bronze Age gold artefacts and native gold by chemical and lead isotope analyses using ICP-mass spectrometry. The analyses of the artefacts indicate that the gold which was used to manufacture the artefacts was alloyed with variable amounts of silver. Beside silver, the concentrations of platinum, osmium, and other trace elements in the gold are low. In addition to the analysis of the chemical composition, lead isotope analyses also provided insights into the provenance of the gold artefacts from the region Georgia-Anatolia-Armenia. No sophisticated treatment of the gold could be detected.
\end{abstract}

Résumé : Ce travail est un projet pilote entre les sciences archéologiques et les sciences naturelles, dont le but est d'explorer les technologies et la provenance d'objets en or, présentés ici dans le cas de la Géorgie et, plus particulièrement, de la mine d'or préhistorique de Sakdrisi. Cette étude comporte l'analyse chimique et isotopique, au moyen de la technique ICP-MS, aussi bien d'objets en or datant de l'Âge du Bronze que d'or natif. L'analyse des objets a montré que l'or utilisé dans leur fabrication était allié à des concentrations variées d'argent. À côté de l'argent, les concentrations de platine, d'osmium et d'autres éléments trace de l'or sont faibles. En plus de l'analyse de la composition chimique, l'analyse des rapports isotopiques du plomb a fourni des indications sur la provenance des objets en or de la région Géorgie-Anatolie-Arménie. Aucun traitement élaboré de l'or n'a pu être identifié.

Keywords: Gold, Prehistoric Mining, Silver, Copper, Mercury, Trace elements, Lead isotopy.

Mots-clés : or, exploitation minière préhistorique, argent, cuivre, mercure, éléments trace, isotopes du plomb.

\section{INTRODUCTION}

The region south of the Great Caucasus (present day Georgia) is known from the Greek myth of the "Golden Fleece". Iason, a Mycenaean hero of royal origin, sailed with the Argonauts from Greece to the Colchis to demand the "Golden Fleece" from king Aietes. Iason successfully looted the fleece with the help of the king's daughter, Medea. The "Golden Fleece" stands as a symbol for the recovery of gold from placers using the skin of an ox or a sheep. The myth of the "Golden Fleece" is proof of the economic wealth of this region and its sources of gold, silver, iron and copper. The richness in gold is verified extraordinarily by the excavations of $5^{\text {th }}$ to $3^{\text {rd }}$ century BC royal graves of the acropolis at Vani, the capital of the kingdom of Colchis. The graves, which are contemporaneous with the Greek colonisation of the eastern coast of the Black Sea, are under excavation by Kacharava and Kvirkvelia (2008).

There is, however, also gold from earlier periods (KuraAraxes Culture) in Georgia. Since the Trialeti Culture (middle of the $3^{\text {rd }}$ millennium BC), gold was more frequently used for jewellery and tomb offerings (Lordkipanidze, 1991). On the occasion of the ongoing excavations by the National Museum of Georgia and the Deutsches Bergbau-Museum Bochum of

* Deutsches Bergbau-Museum Bochum - D 44787 Bochum. andreas.hauptmann@bergbaumuseum.de

** Institut für Mineralogie - Altenhöferallee 1, Goethe-University Frankfurt/Main, D 60438 Frankfurt. sabine.klein@kristall.uni-frankfurt.de 
the prehistoric gold mine of Sakdrisi, ca. $50 \mathrm{~km}$ southwest of Tbilisi, close to the centre of the Middle Bronze Age Trialeti Culture, we analysed Bronze Age gold artefacts (beads and sheet metal) and native gold from the Great Caucasus and Transcaucasia. It is the aim of the present study to search for the source(s) of the Bronze Age gold in Georgia: are the artefacts made locally, or were they imported? In addition, we studied the composition of the gold in order to gain an insight into the metallurgical techniques possibly employed for producing the artefacts. The analytical data and the archaeological context will be published in greater detail in Hauptmann et al. (in press) and Stöllner et al. (in press).

\section{Gold DEPOSits IN GeORGIA}

The gold districts in Georgia are shown in Figure 1. They were partly exploited at the beginning of the $19^{\text {th }}$ century (Godabrelidze, 1933). Today, gold reserves in Georgia are estimated to ca. $100 \mathrm{t}$ (Twaltschrelidze, 2001).

(Sub-) recent placers occur in Swanetia and Racha in the Great Caucasus. This gold originates from hydrothermal veins in Cretaceous-Jurassic shales (Godabrelidze, 1933), and is possibly re-mobilised primarily from Proterozoic to Palaeozoic crystalline rocks with a geological age between 60 and $>570 \mathrm{Ma}$ (Adamia, 2004). An estimated $8.000 \mathrm{~kg}$ of gold were exploited in this region. From the area north of Tbilisi, fossil placers are known in Pleistocene sediments. They probably originate from hydrothermal quartz veins in Cretaceous shales, similar to Swanetia. Gold placers in the lower course of the Tschorochi river near Batumi may have their origin in the Artvin area, where copper-gold and silver deposits are under exploitation at Gümüshan and Murgul (Bayburtoğlu and Yildirim, 2008).

The gold district of Sakdrisi, west of Bolnisi, is the most important one in Georgia (Fig. 1). Both gold placers and primary deposits occur here. Dozens of 'ancient' mines were surveyed. The gold deposits were formed mainly during the Alpidic metallogenesis (Jurassic- Cretaceous) and are part of the "Tethyan Eurasian Metallogenetic Belt" (TEMB) (Moon et al., 2001). They are embedded in volcanic rocks. In addition, Palaeozoic-Proterozoic granitic rocks occur. Gold also occurs in volcanic rocks in the northern part of Armenia.

Important copper bearing volcanogenic massive sulfide deposits (VMS) with gold, namely those of David Garedschi and of Madneuli, are genetically connected with Sakdrisi. They are also geologically comparable to ore deposits in the Artvin (Moon et al., 2001). Madneuli is bound to a rhyolitic dome located above an intrusive complex of granodioritic rocks. The K-Ar dating of Madneuli points to 85-93 Ma, and the one of Sakdrisi to 78-84 Ma (Gugushvili et al., 2002). Due to its geochemical stability, gold is relatively enriched close to the surface. We therefore suggest that prehistoric mining at the outcrop of Madneuli also involved gold.

\section{The PREHISTORIC GOLD MINE OF SAKDRISI}

At Sakdrisi, a criss-crossing swarm of vertically dipping hydrothermal gold-quartz veins with hematite and minor amounts of copper minerals were exploited (Fig. 2). The ancient mining reached a depth of ca. $25 \mathrm{~m}$. The ample prehistoric mining is attested by the masses of hammer stones collected from the waste dumps, and from the underground mining as well. Backfillings left in the ancient working pockets contained Kura-Araxes pottery, and also charcoal from fire setting and from lightening. A set of seven ${ }^{14} \mathrm{C}$ data carried out so far revealed mining activities spanning the period from the second half of the $4^{\text {th }}$ to the middle of the $3^{\text {rd }}$ millennium BC (Stöllner et al., 2008).

Gugushvili et al. (2002) estimated an average of $1.03 \mathrm{ppm}$ of gold in the Sakdrisi district. Local enrichments, however, reach $>10$ and up to $500 \mathrm{ppm}$ of gold (Hauptmann et al., in press; pers. comm. M. Natsvishvili, M. Tschochonelidze). Our own investigations proved that such enrichments occur in vugs filled with loose material including clay, hematite, and quartz. The gold that was washed from the backfillings of the prehistoric mine proved to be a very fine grained material. The grains are hardly visible with the naked eye. It is questionable whether this is the material that was exploited in ancient times. Metallurgical processes that would be necessary to extract the gold from this type of material, such as amalgamation or lead melting, were not known in the Bronze Age. Perhaps local enrichments might have created classical bonanzas (see Stöllner et al., in press). Presently, it is too vague to come up with an estimation of the gold exploited at the ancient mine of Sakdrisi, even if survey work suggests a figure of $5000 \mathrm{~m}^{3}$ of worked rock at or in the mine.

\section{Analytical inVestigation}

20 alluvial gold specimens and samples of gold ore from the Sakdrisi mine were washed from several tons of material collected using sluice boxes and pans. In addition, 70 Middle to Late Bronze Age gold artefacts, mainly from Kurgans in Southern Georgia, were sampled.

In our study, we analysed artefacts and native gold in a 'destructive' manner. Mounted samples were prepared for investigations by SEM for a first overview. We applied elec- 


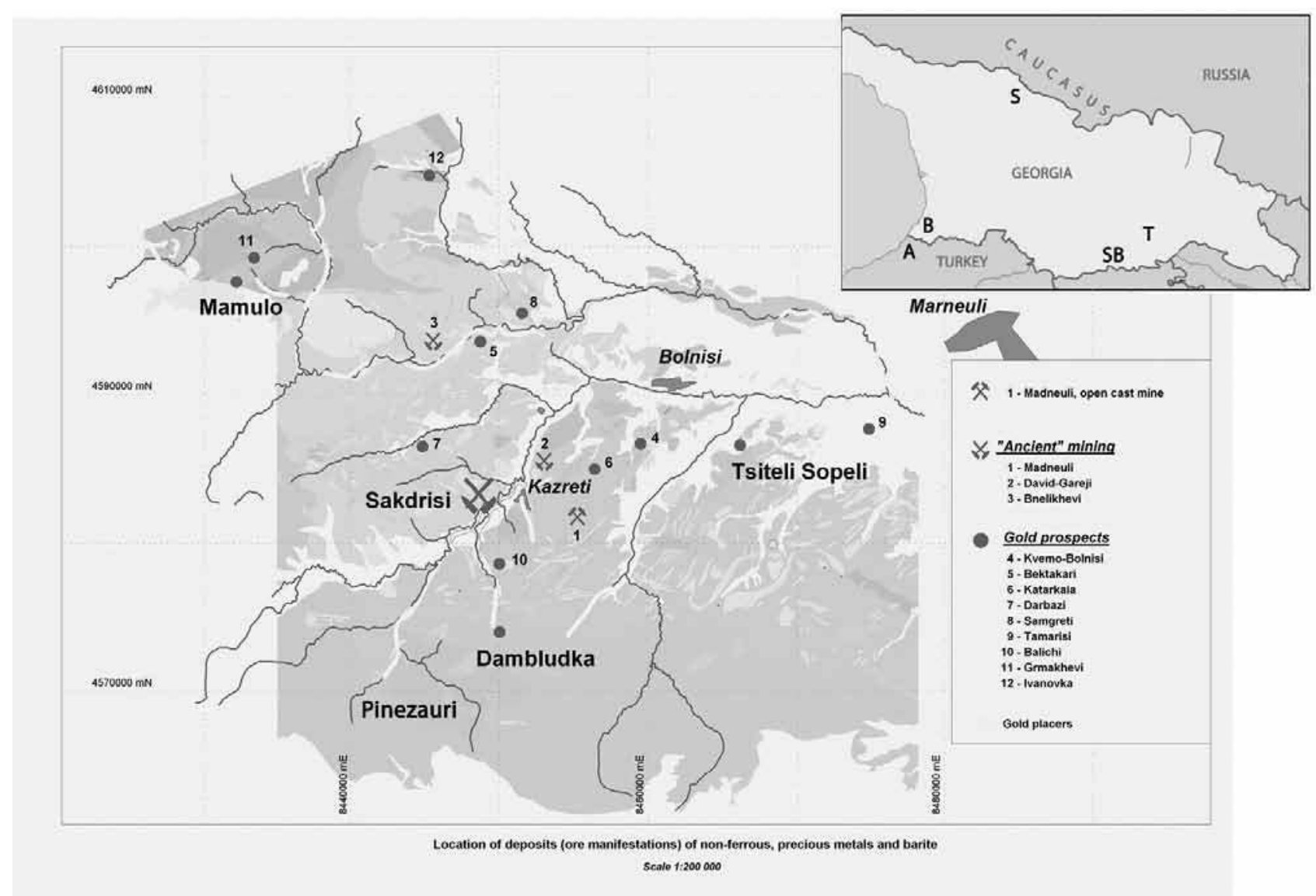

Figure 1: (See colour plate) Gold districts in Georgia (upper right) and a simplified geological overview of the Sakdrisi-Bolnisi gold district. A number of primary gold deposits are shown, combined with recent placer deposits. The prehistoric mine of Sakdrisi is closely connected with the volcanogenic massive sulphide deposits of Madneuli. Dozens of 'ancient' remains of mining activities were surveyed. The entire region contains mainly Cretaceous to Tertiary volcanic rocks, and Palaeozoic-Proterozoic magmatic rocks (Dambludka, Mamulo). Modified after the geological map of the Sakdrisi-Bolnisi-Reviers (1:200.000), Georgia, unpublished version. With permission of M. Tschochonelidze, Tbilisi. Abbrevations: A = Artvin; B = Batumi with Tschorochi; S = Swanetia, Racha; SB = Sakdrisi, Bolnisi; T = Tbilisi. Figure 1 : (Voir planche couleur) Districts de l'or de la Géorgie (en haut à droite) et vue géologique simplifiée d'ensemble du district de Sakdrisi-Bolnisi. Certains gisements d'or sont localisés, combinés avec des placers récents. La mine préhistorique de Sakdrisi est très liée au gisement volcanogénique à sulfures massifs de Madneuli. Des dizaines de vestiges anciens d'activités minières ont été récoltés. De plus la région possède particulièrement des roches tertiaires et crétaciques volcaniques et des roches paléozoïque-protérozoïque magmatiques (Dambludka, Mamulo). Modifications selon la carte géologique de Sakdrisi-Bolnisi-Reviers (1:200.000), Géorgie, version non publiée. Avec la permission de M. Tschochonelidze, Tbilisi. Abréviations: $A=$ Artvin; $B=$ Batumi avec Tschorochi; $S=$ Swanetia, Racha; SB = Sakdrisi, Bolnisi; $T=$ Tbilisi.

tron microscopy with a wavelength system (JEOL 8900 Superprobe) for the quantification of the main elements and a selection of trace elements, in order to characterise the bulk chemical composition of the material. This preliminary step is necessary in order to identify the appropriate dissolution factor for solution based ICP-MS and also as a base for the LA calculation of the trace elements. Trace element and lead isotope analyses were carried out in Frankfurt using a Multi-Collector ICP-Mass Spectrometer (Finnigan MAT eNeptun). Generally, due to the high cultural value of the gold objects, destructive sampling such as the one permitted here is an exception. We therefore utilised, for comparison, Laser Ablation ICP-Mass Spectrometry analysis in a nondestructive mode as well. This method is most suitable for analysing objects from which only very little material or even none is available for analysis. In Frankfurt, a UP-213 laser ablation system (New Wave) was used, coupled with a Finnigan Element2 Mass Spectrometer. A measurement method was developed to combine extern standard solutions. Its reproducibility was verified by multiple measurements (Bendall, 2003). In order to verify the precision of the method, the copper standard SRM C1252 was used. 


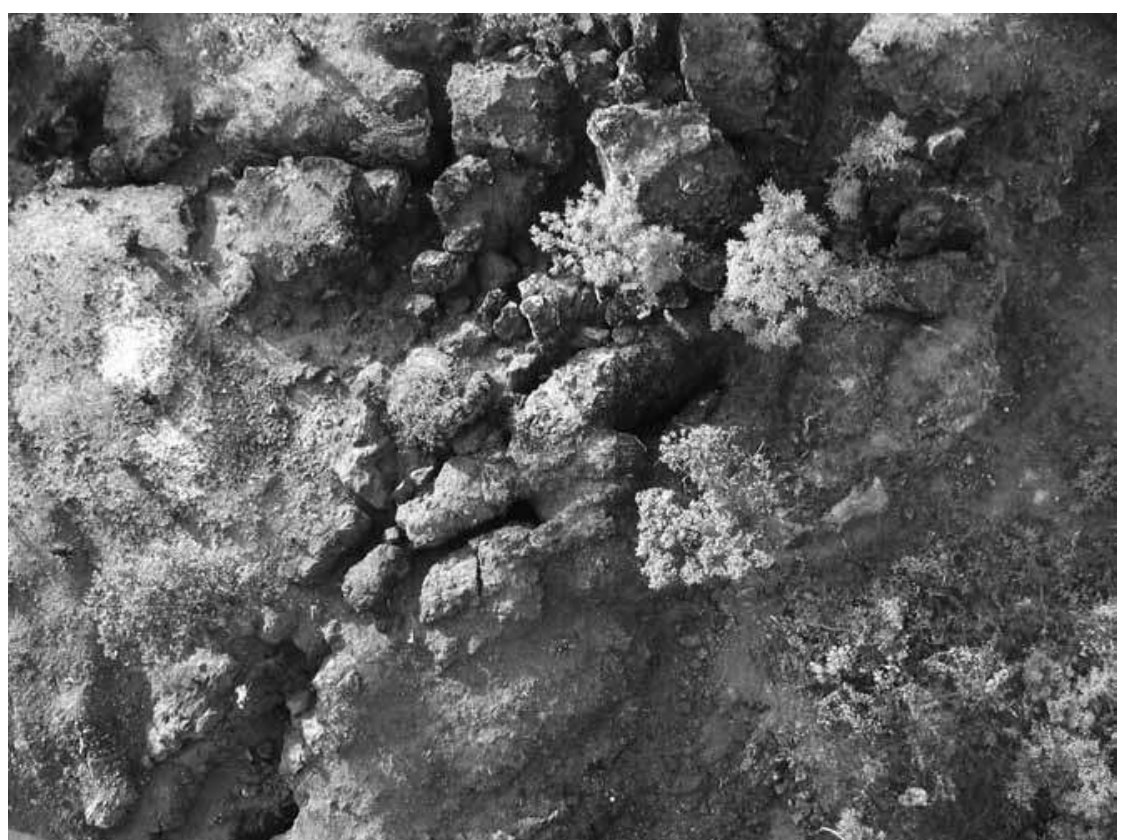

Figure 2: Aerial photograph of the prehistoric mine of Sakdrisi after the removal of the vegetation. Note the exploitation of criss-cross and vertically dipping quartz-hematite-gold veins.

Figure 2 : Photographie aérienne de la mine préhistorique de Sakdrisi, après enlèvement de la végétation. L'on note l'exploitation de filons de quartz-hématite-or en croisillons et descente verticale.
With this procedure, a large number of elements can be analysed with a high degree of precision. The typical precision obtained for ${ }^{207} \mathrm{~Pb} /{ }^{206} \mathrm{~Pb}=+/-0.00006$ and for ${ }^{208} \mathrm{~Pb} /{ }^{206} \mathrm{~Pb}=+/-0.0002$. The average extern precision is $+/-0.00009$ for ${ }^{207} \mathrm{~Pb} / 206 \mathrm{~Pb}$ and $+/-0.0003$ for ${ }^{208} \mathrm{~Pb} /{ }^{206} \mathrm{~Pb}$. With these results, LA-ICP-MS represents the first method of choice for 'non-destructive' analysis of gold objects.

Problems occur if the overall low concentrations of lead in gold are extreme, and also if contaminations of mercury have taken place. This makes a precise analysis of ${ }^{204} \mathrm{~Pb}$ difficult, and it prevents its use in some cases. However, important archaeometric information is still available by the analysis of the remaining lead isotopes: ${ }^{206} \mathrm{~Pb},{ }^{207} \mathrm{~Pb}$ and ${ }^{208} \mathrm{~Pb}$. We will present the specificities of the different applications of this method in our upcoming paper.

\section{Results AND Discussion}

By comparing the native gold collected from various localities in Georgia and the analysed gold artefacts, it becomes clear that the latter are generally richer in trace elements than the native gold. The native gold samples are, except for their silver concentrations, remarkably pure. Neither PGE inclusions, nor Ag-Au tellurides or Ag sulfides were detected.

We suggest that the higher trace element content of the artefacts is due to an incomplete separation of the gold from the associated heavy mineral fractions, as observed in
Mamulo (Fig. 3). Such impurities could be partly incorporated from the heavy minerals into the gold during the (s) melting process.

\section{Silver in gold}

Both gold artefacts and native gold show a large range of silver contents, from 1 to $38 \mathrm{wt} \% \mathrm{Ag}$. Silver is homogeneously distributed within the gold, and no enrichment of gold was observed as it may occur in nature, or caused by anthropogenic treatments. $\mathrm{Ag}$ concentrations of this range are not anomalous for native gold, and the match with the silver contents of the artefacts points out that silver was not intentionally added to the gold. If intentionally added, the alloy would be expected to be remarkably contaminated by lead from the cupellation process of Ag-bearing lead ores. Because the lead concentrations range within the lower ppm level (Fig. 4), we strongly exclude the possibility of an intentional adding of silver to the gold. Obviously, no parting was performed during the Middle and Late Bronze Age in Georgia.

\section{Mercury - a trappy element}

Among the gold grains that were washed, e.g., in a small river near Sakdrisi, gold-silver amalgams were identified. There are two possible explanations for this occurrence: 1 . the amalgams are native and occur in the ore deposits, and 2. the amalgams are anthropogenic products and represent 


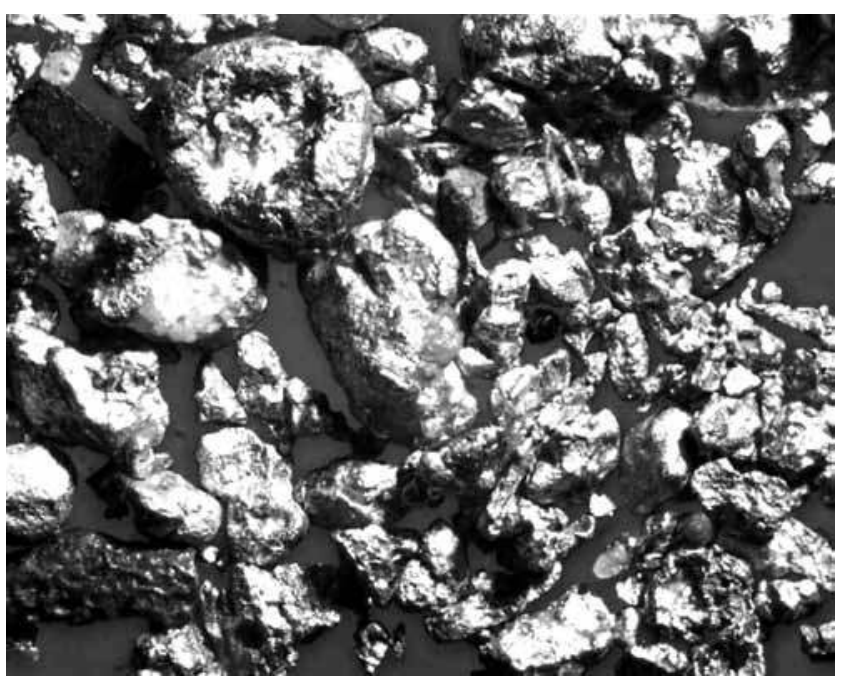

Figure 3: (See colour plate) Alluvial gold, Mamulo, SakdrisiBolnisi-district. The concentrate is contaminated by copper minerals (blue), magnetite (black) and quartz (white). We cannot exclude the possibility that comparable impurities would have been incorporated (in parts) in gold in prehistory. Especially copper minerals could lead to 'anomalous' concentrations in the final object. Width of picture: ca. $2 \mathrm{~mm}$.

Figure 3: (Voir planche couleur) Or alluvionnaire, Mamulo, district de Sakdrisi-Bolnisi. Le concentré est contaminé par des minerais de cuivre (bleu), magnétite (noire) et quartz (blanc). À ne pas exclure la possibilité d'incorporation dans l'or (en partie) d'impuretés comparables pendant la préhistoire. Les minerais de cuivre en particulier pourraient amener à des concentrations " anormales " dans l'objet fini.

debris from historical gold washers' activities. Aspects in the favour of the first explanation: gold-mercury compounds occur in the deposits of the Sakdrisi-Bolnisi district (Moon et al., 2001). This is not uncommon, as natural gold may contain up to $6 \%$ mercury, as shown by the paleo-placer deposits of Witwatersrand (Oberthür and Saager, 1986). Placer gold in Scotland contained up to 8\% mercury (Leake et al., 1998). An argument in favour of the second explanation is the fact that historical sources from Georgia report on multiple gold extraction by amalgamation during the $19^{\text {th }}$ century. This seems to have been a widespread technique, and Dilabio et al. (1988) reports on worldwide anthropogenic pollution by mercury in gold placer deposits. The distinct porous texture, as shown in Figure 5, is typical for amalgamated gold, its origin being from the evaporation of mercury following the heating of the gold amalgam. As we could not exclude the possibility of an anthropogenic input of mercury rich mineral in the gold grains from Sakdrisi, 'suspicious' grains were sorted out prior to the lead isotope analysis in order to avoid contaminations of the natural gold. $\mathrm{Hg}$-containing grains make the analysis of ${ }^{204} \mathrm{~Pb}$ impossible, because the isotopes ${ }^{204} \mathrm{Hg}$ and ${ }^{202} \mathrm{Hg}$ interfere with ${ }^{204} \mathrm{~Pb}$.

\section{Copper in gold}

Alluvial gold from Georgia contains far below 1\% copper, while the gold artefacts contain between 1 and 7.7 wt $\%$ $\mathrm{Cu}$. The question is whether copper was incorporated in the metal, due to the incomplete separation of the gold from the placer material, or rather if it was incorporated by a re-melting of the gold objects originally decorated with e.g. granulation, i.e., granules soldered with copper. We exclude this possibility, because granulation was not common in Georgia during this period (Dschaparidze, 2001). We ourselves suggest that copper was enriched in the gold, because the gold

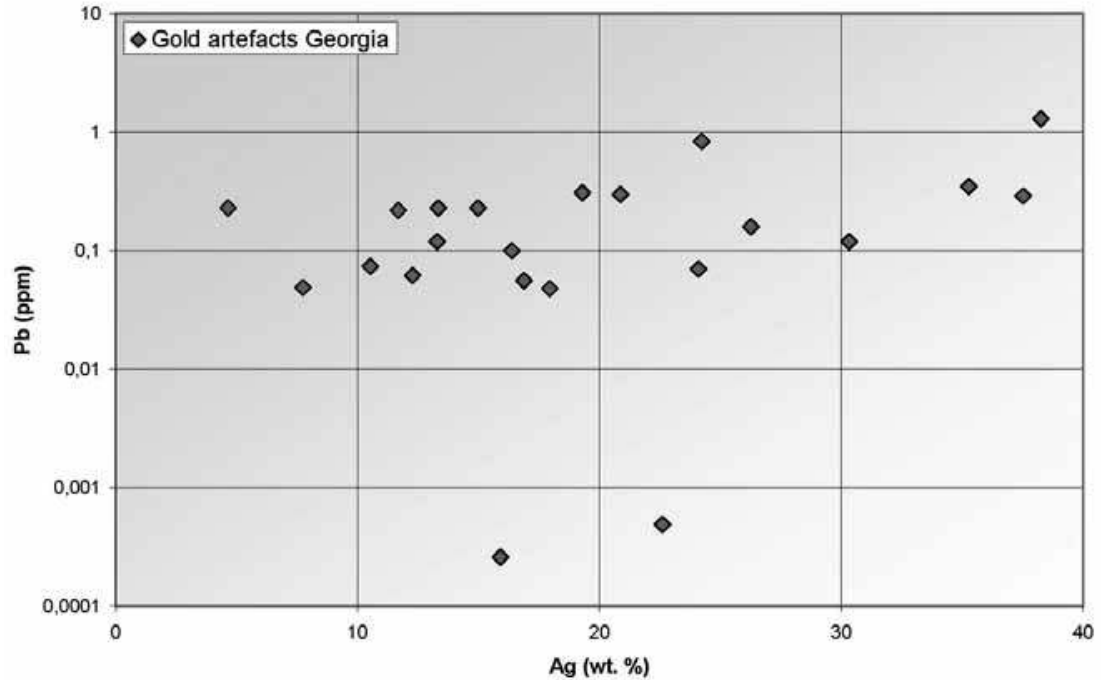

Figure 4: $\mathrm{Pb} / \mathrm{Ag}$ diagram of gold artefacts from Georgia. Very low Pb concentrations and any missing correlation between $\mathrm{Pb}$ and $\mathrm{Ag}$ indicate that the noble metal was not intentionally added to the gold, but that it originates in the ore deposits.

Figure 4 : Diagramme Pb/Ag des objets d'or de Géorgie. Les concentrations très faibles de $\mathrm{Pb}$ et l'absence de corrélation entre le $\mathrm{Pb}$ et l'Ag indiquent que le métal noble n'a pas été intentionnellement additionné à l'or, mais qu'il appartient au gisement. 


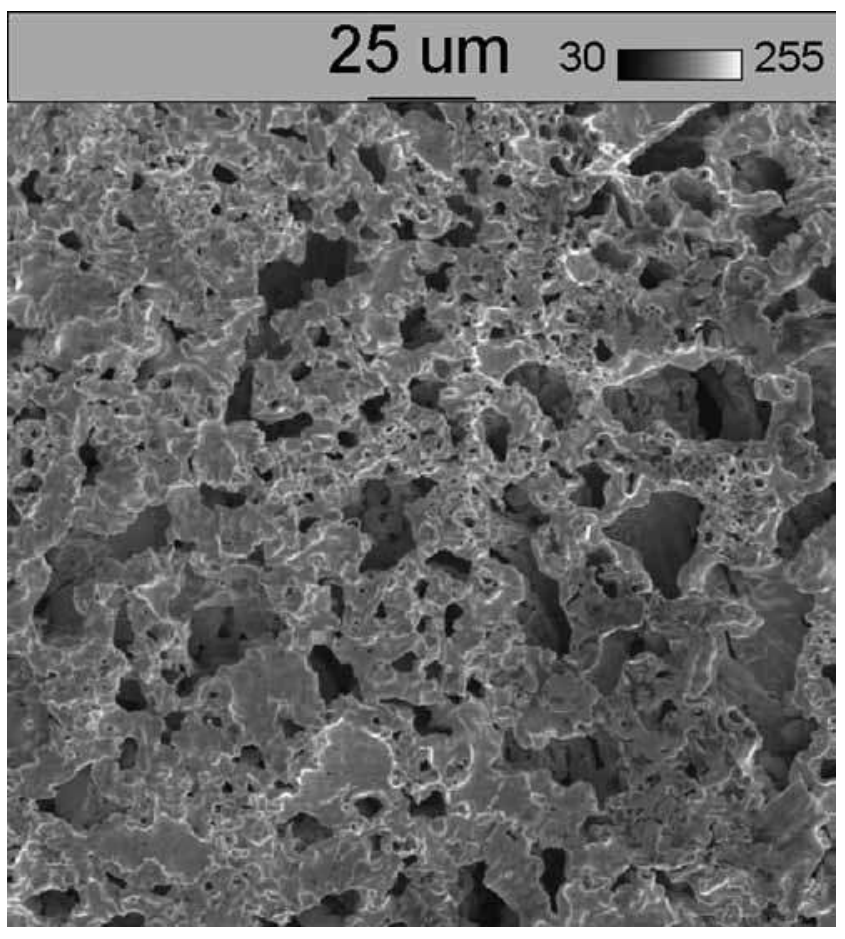

Figure 5: Gold-amalgam grain from a small river in the SakdrisiBolnisi-district. The Au-Ag-Hg alloy consists of $80-82 \% \mathrm{Au}, 3.5-$ $5.5 \% \mathrm{Ag}$ and $14-15 \% \mathrm{Hg}$. The porous texture suggests a gold extraction by amalgamation rather than a natural amalgam (which is suggested to occur in this region as well). SEM image, secondary electron mode. Source: Hauptmann and Gambaschidze (2006).

Figure 5 : Grain d'amalgame d'or provenant d'un ruisseau du district de Sakdrisi-Bolnisi. L'alliage d'Au-Ag-Hg contient 80-82\% Au, 3,55,5\% Ag et $14-15 \% \mathrm{Hg}$. Sa texture poreuse suggère une extraction d'or par amalgamation plutôt qu'un amalgame naturel (qui peut aussi être présent dans cette région). Image $M E B$, en mode d'électrons secondaire. Source: Hauptmann and Gambaschidze (2006).

grains were first insufficiently separated from copper mineral grains in the placer material (see above and Fig. 3), and subsequently introduced into the gold metal during the smelting or melting process.

\section{Results of trace element analysis}

Concentrations of other trace elements are very low. Platinum (up to $6 \mathrm{ppm}$ ) and osmium (up to $7 \mathrm{ppm}$ ) seem to be correlated. Platinum group elements are suggested to be typical for alluvial gold, especially in a fluvial environment, and might be incorporated in gold. Gold in hydrothermal veins contain Pt only in the sub-ppb level. Tin reaches 3 $50 \mathrm{ppm}$ in the gold artefacts. This is in an order of magnitude lower by a factor of one to two than those analysed by Hartmann (1982) in European gold objects. In contrast, native gold from Georgia is almost devoid of tin. Based on the available data, we cannot claim with certainty that tin is a tracer for placer gold.

\section{Results of lead isotope analysis}

Lead concentrations in native gold are in most cases close to the detection limit for isotope analyses; in the artefacts, lead is only up to $2 \mathrm{ppm}$. Hence, it was not possible to analyse the lead isotope ratios for all samples. The results obtained from gold artefacts, native gold and gold bearing heavy mineral fractions are shown in Figure 6. For comparison, we also included lead isotopes of some copper ores, because of their close paragenesis with gold.

Most of the artefacts plot around a mixing line which crosses overlapping isotope fields of ore deposits in the Aegean, Anatolia and Armenia. This means that they are compatible with an origin of the ore deposits in the Mesozoic folded mountain belt of the Pontides and the Transcaucasus. More precisely, we found an accumulation of isotope ratios of artefacts which matches the composition of the Sakdrisi gold itself, and that of the ores from Madneuli. The results are also compatible with copper ores from Murgul, where at least prehistoric copper mining is attested (Lutz, 1990). High ${ }^{208} \mathrm{~Pb} /{ }^{206} \mathrm{~Pb}$ vs. ${ }^{207} \mathrm{~Pb} /{ }^{206} \mathrm{~Pb}-$ ratios, as represented by native gold samples from Mamulo, Pinezauri and Dambludka in the Sakdrisi-Bolnisi district (see upper right in Fig. 6), originate from geologically very old deposits, as they occur in Proterozoic crystalline rocks (see Fig. 1). Such isotope ratios were observed only in two gold artefacts, originating from a locality situated at a considerable distance from Sakdrisi, in Eastern Georgia. One of the two outliers in the lower left side of the diagram comes close to the isotopic pattern of $4^{\text {th }}$ millennium BC litharge from Fatmali-Kalecik in the upper Euphrates area (unpublished data Bochum). There is evidence of prehistoric silver extraction at Fatmali-Kalecik (Hess et al., 1999), but the ore deposit is also gold bearing.

\section{Conclusions}

Excavations proved that the Sakdrisi gold mine is the oldest in the world. This data shows that during the Early Bronze Age, gold exploitation was by no means confined to the exploitation of placers. Bronze Age gold artefacts in Georgia were made of natural gold-silver alloys. We could not detect exactly how gold was beneficiated, but we suggest that copper concentrations in the artefacts are caused by an insufficient separation of accessory minerals. As to the 


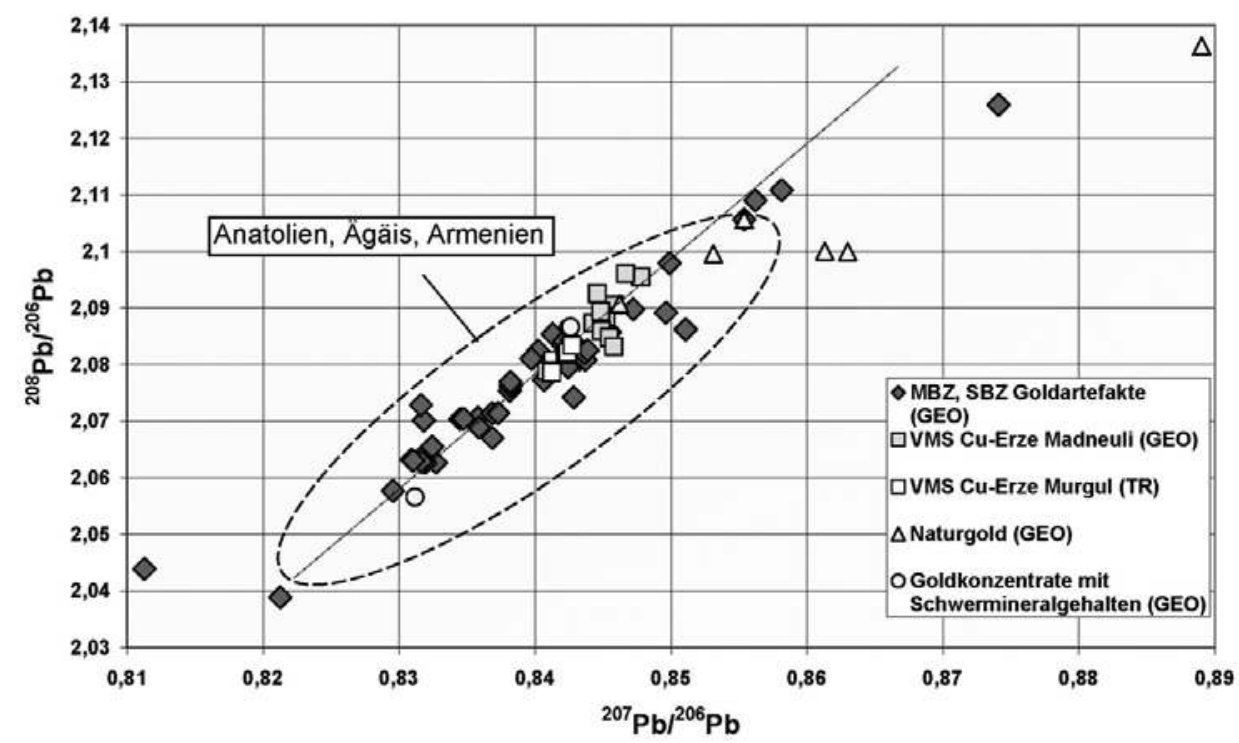

Figure 6: (See colour plate) ${ }^{208} \mathrm{~Pb} /{ }^{206} \mathrm{~Pb}$ vs. ${ }^{207} \mathrm{~Pb} /{ }^{206} \mathrm{~Pb}$-ratios of gold artefacts and native gold from Georgia. For comparison: lead isotope ratios of copper and lead ores and copper and lead-slags and artefacts from the Aegean, Anatolia and Armenia are shown (shaded area; according to Seeliger et al., 1985; Hauptmann et al., 2002; Pernicka et al., 2003; Meliksetian et al., 2003). Data from the VMS coppergold deposits at Madneuli from Dschaparidze (in prep.), and at Murgul from Lutz (1990). Abbreviations: VMS = Volcanogenic Massive Sulphide Deposit; MBA = Middle Bronze Age; LBA = Late Bronze Age.

Figure 6: (Voir planche couleur) Rapports ${ }^{208} \mathrm{~Pb}{ }^{206} \mathrm{~Pb}$ vs. ${ }^{207} \mathrm{~Pb}{ }^{206} \mathrm{~Pb}$ pour les objets d'or et l'or natif de Géorgie. Pour comparaison : rapports isotopiques de minerais de cuivre et de plomb, de scories de cuivre et de plomb et d'objets provenant de l'Egée, d'Anatolie et d'Arménie, comme illustré (zone ombrée; selon Seeliger et al., 1985; Hauptmann et al., 2002; Pernicka et al., 2003; Meliksetian et al., 2003). Données des gisements VMS de cuivre-or de Madneuli selon Dschaparidze (en préparation) et de Murgul selon Lutz (1990). Abréviations: VMS = gisement à sulfures massifs volcanogéniques; $M B A=\hat{A g e} d u$ Bronze moyen; $L B A=\hat{A g e} d u$ Bronze récent.

provenance of the gold artefacts analysed, we conclude that lead isotope analysis is a useful tool for this purpose. The genetic connection of the gold from Sakdrisi with volcanogenic ore deposits (VMS) suggests a comparison with copper ores from such sources as well. However, mercury concentrations have to be carefully analysed in order to verify their anthropogenic or natural origin. We were able to show that many of the gold artefacts from Georgia were most probably produced using gold from deposits located in the mountain range of the TEMB. The isotope data could support the use of local gold ores from the Sakdrisi and the Madneuli mines for the making of the artefacts, provided that mining activities from the Middle and Late Bronze Age will hopefully be discovered in the future. In order to provide more detailed answers to the questions posed by archaeology, we are in need of a more extensive database pertaining to the areas under consideration. Do gold artefacts found, e.g., in a single Kurgan, but with different isotopic signatures, indicate the fact that they come from different geographic sources? Or were they smelted using gold from one gold district only, such as the one of Sakdrisi-Bolnisi? What is the variety of isotopic compositions in a single district with different primary mineralisations and placers? Sampling of more gold artefacts and native gold appears necessary, and additional tracers are needed.

\section{Acknowledgements}

The authors gratefully acknowledge all the persons and institutions involved for providing us with gold objects and for help in extracting gold from the geological context. Our thanks go to the VolkswagenStiftung, Hanover, for financial support. 


\section{References}

Adamia, S. (ed.), 2004. Geological Map of Georgia. Tbilisi, Union GEO-ECO.

BayburtoğLu, B. and Yildirim, S., 2008. Gold and Silver in Anatolia, in Ü. Yalcin (ed.), Anatolian Metal IV. Der Anschnitt, Beiheft 21. Bochum, Deutsches Bergbau-Museum, 43-53.

Bendall, C., 2003. The application of trace element and isotopic analyses to Celtic gold coins and their metal sources. Dissertation, University Frankfurt/Main, Germany.

Dilabio, R.N.W., Newsome, J.W., McIvor, D.F. and Lowenstein, P.L., 1988. The Spherical Form of Gold: Manmade or Secondary? Economic Geology 83: 153-162.

Dschaparidze, I., (in prep.). Bronze Production in Georgia (III-I millennia B.C.). Dissertation, Staatliche Ivane Dschawachaschwili-Universität, Tbilisi, Georgia.

Dschaparidze, O., 2001. Zur frühen Metallurgie Georgiens vom 3. bis zum 1. Jahrtausend v. Chr, in I. Gambaschidze, A. Hauptmann, R. Slotta, Ü. Yalcin (eds.), Georgien - Schätze aus dem Land des Goldenen Vlies. Bochum, Deutsches Bergbau-Museum, 92-119.

Godabrelidze, S.A., 1933. Mineral resources in the Socialistic Republic of Georgia. Tiflis, Gostehizdat Gruzii "Tehnika da Šroma”, Tbilisi (in Russian).

Gugushvili, V.I., Akhvlediani, R., Natsvlishvili, M. and HaRT, I., 2002. Two stages of gold mineralization within Sakdrisi deposit (Bolnisi Mining District, Georgia). Geologica Carpathica Special Issue 53: 1-5.

Hartmann, A., 1982. Prähistorische Goldfunde aus Europa II. Studien zu den Anfängen der Metallurgie 5. Berlin, Mann Verlag.

Hauptmann, A. and Gambaschidze, I., 2006. Vom Kupfer zum Gold - Das Deutsche Bergbau-Museum in Georgien, in S. Brüggerhoff, M. Farrenkopf, W. Geerlings (eds.), Montan- und Industriegeschichte. Festschrift R. Slotta zum 60. Geburtstag. Paderborn, Schöningh, 129-142.

Hauptmann, A., Bendall, C., Brey, G., Dschaparidze, I., Gambachidze, I., Klein, S., Prange, M. and Stöllner, T., IN PRESS. Gold in Georgien. Analytische Untersuchungen an Goldartefakten und Naturgold aus dem Kaukasus und dem Transkaukasus, in S. Hansen, A. Hauptmann, I. Motzenbäcker (eds.), Von Majkop nach Trialeti - Gewinnung und Verbreitung von Metallen und Obsidian in Kaukasien im 4.-2. Jahrtausend v. Chr. Archäologie in Eurasien.

Hess, K., Hauptmann, A., Wright, H. and Whallon, R., 1999. Evidence of fourth millennium $B C$ silver production at Fatmali-Kalecik, in Th. Rehren, A. Hauptmann, J. Muhly (eds.), Metallurgica Antiqua: in honour of Hans-Gert Bachmann and Robert Maddin. Der Anschnitt, Beiheft 8. Bochum, Deutsches Bergbau-Museum, 57-67.

Kacharava, D. and Kvirkelia, G., 2008. Wine, Worship and Sacrifice of Ancient Vani. New York, Institute for the Study of the Ancient World.
Leake, R.C., Chapman, R.J., Bland, D.J., Stone, R., Cameron, D.G. and STYLES, M.T., 1998. The origin of alluvial gold in the Leadhills area of Scotland: evidence from interpretation of internal chemical characteristics. Journal of Geochemical Exploration 63: 7-36.

LordKipanidze, O., 1991. Archäologie in Georgien. Von der Altsteinzeit bis zum Mittelalter. Quellen und Forschungen zur prähistorischen und provinzialrömischen Archäologie. Bd. 5. Weinheim: VCH Verlagsgesellschaft.

LuTz, J., 1990. Geochemische und mineralogische Aspekte der frühen Kupferverhüttung in Murgul/Nordost-Türkei. Dissertation Nat.Math. Gesamtfakultät, Universität Heidelberg, Germany.

Meliksetian, Kh., Pernicka, E., Avetissyan, P. and Simonyan, H., 2003. Chemical and lead isotope characterisation of Middle Bronze Age bronzes and some Iron Age antimony objects, in Archaeometallurgy in Europe: international conference, 24-25-26 September 2003, Milan, Italy: proceedings. Milano, Associazione Italiana di Metallurgia, 311-318.

MigineishVILI, I.R., 2002. A possible model of formation for the Madneuli copper-gold deposit. Proceedings of the Geological Institute of the Georgian Academy of Science, New series 117: 472-479.

Moon, C.J., Gotsiridze, G., Gugushvili, V., Kekelia, M., MigineishVili, R., OtKhmeZuri, Z. and ÖZgür, N., 2001. Comparison of Mineral Deposits between Georgian and Turkish sectors of the Tethyan Metallogenic Belt, in A. Piestrzynski (ed.), Mineral Deposits at the Beginning of the $21^{\text {st }}$ Century. Lise, Balkema, 309-312.

Oberthür, T. and SAager, R., 1986. Silver and Mercury in Gold Particles from the Proterozoic Witwatersrand Placer Deposits of South Africa: Metallogenetic and Geochemical Implications. Economic Geology 81: 20-31.

Pernicka, E., Eibner, C., Öztunali, Ö. and Wagner, G.A., 2003. Early Bronze Age Metallurgy in the North-East Aegean, in G.A. Wagner, E. Pernicka, H.P. Uermann (eds.), Troia and the Troad. Scientific Approaches. Berlin, Heidelberg, New York, Springer, 143-172.

Seeliger, T., Pernicka, E., Wagner, G.A., Begemann, F., SChmitt-STrecker, S., EibNer, C. and ÖZtunali, Ö., 1985. Archäometallurgische Untersuchungen in Nord- und Ostanatolien. Jahrbuch Römisch-Germanisches Zentralmuseum 32: 597-659.

Stöllner, T., Gambaschidze, I., Hauptmann, A., Mindiaschwili, G., Gogotschuri, G. and Steffens, G., in press. Goldbergbau in Südostgeorgien - Neue Forschungen zum frühbronzezeitlichen Bergbau in Georgien, in S. Hansen, A. Hauptmann, I. Motzenbäcker (eds.). Von Majkop nach Trialeti - Gewinnung und Verbreitung von Metallen und Obsidian in Kaukasien im 4.-2. Jahrtausend v. Chr. Archäologie in Eurasien.

Twaltschrelidze, A.G., 2001. Erzlagerstätten in Georgien, in I. Gambaschidze, A. Hauptmann, R. Slotta, Ü. Yalcin (eds.), Georgien - Schätze aus dem Lande des Goldenen Vlies. Bochum, Deutsches Bergbau-Museum, 78-89. 